\title{
VALUE JUDGMENT IN WAR FOR THE PLANET OF THE APES MOVIE: A LITERATURE STUDY
}

\author{
I Wayan Arya Jaya Sedayatana ${ }^{1}$, I Dewa Ayu Devi Maharani \\ Santika ${ }^{2}$, Ida Bagus Gede Nova Winarta ${ }^{3}$ \\ Mahasaraswati Denpasar University, Indonesia ${ }^{1,2,3}$ \\ aryasedayatanafunz@gmail.com¹; devimaharani17@gmail.com²; \\ gusdnova@gmail.com ${ }^{3}$
}

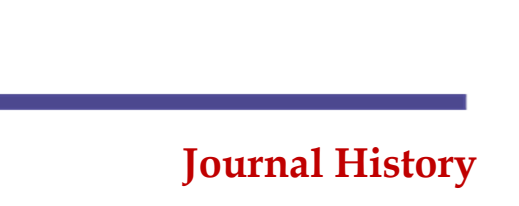

Submitted 22nd December 2021

Revised 20 th January 2022

Accepted 23rd January 2022

Published 24th January 2022

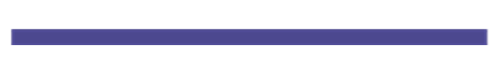

Keywords:

moral judgment; value Judgment; war for the planet

of the apes

\begin{abstract}
According to Trusted (1987), Moral judgment is verbally embodied in statement, sentences that assert that something or is not the case that can therefore be true or false. It can be found in the movie in many genres especially when there are conflicts in the movie. This study concerns with the analysis of one of the moral judgment types: Value Judgment. The data taken from War for the Planet of the Apes movie and they are collected through observation and note taking technique. The theory of Trusted (1987) is used to analyse the value judgment type. The result shows that there are some values judgments appear in the movie and are uttered not just by the main character, but also the other characters in the movie.
\end{abstract}




\section{INTRODUCTION}

Literature is an art in which there are many aspects involved, specifically feeling. Literature can be classified into two genres, they are imaginative such us short story, novel, poetry, movie and non-imaginative for example easy, critics, biography, and also auto biography, memoir, diary, history. According to Wellek and Warren (1956:94) literature is a beautiful writing because it contains aesthetic values. The great form and absolutely amazing effect are achieved when it is arranged a unity of content and expression, form and language bringing message and value of life. Through literature works, the writer or author usually deliver some values about life. The values usually experienced by people in their daily lives. According to Trusted (1987), there terms of moral value and judgment value. Moral judgment is more to the objective picture about certain value that people experience during their lives. Meanwhile moral Judgment concerns in the judgment of someone about something in the form of words no matter whether the person he judges is wrong or right.

And the differences of moral value and moral judgment, moral value is an objective picture of human actions in carrying out their daily routines, with this meaning moral is often associated with code and the nature of humans who want life in comfort. And moral judgments is when someone judges other in the form of words and does not care who is right and who is wrong.

There are some previous studies which discuss about Moral messages on a literature work, such as novel or movie. The first thesis is written by Pratiwi (2019) under the title "The Analysis of Moral Values in A Walk to Remember found in novel written by Nicholas Sparks". The study focused on analyzing what kind of moral value found in the novel "A Walk to Remember", The second thesis is written by Sari (2019) with the title "An Analysis of Moral Values seen in the novel "Gulliver's Travel", The third article are written by Yanthi, Sedang, and Suardhana (2017) under the title An Analysis of Context of Situation in Code Switching found in the movie "Chick-in Bangkok", the fourth thesis is written by Riani (2019) under the title an analysis of moral aspect in "Beauty and The Beast" Movie, the fifth article is written by Steffens (2020) with entitled "the influence of music on moral judgment of movie scenes and felt emotions". Most of the articles found discuss about moral value and there are only a few number of articles about moral judgments, therefore this study tries to do an analysis about it on the movie "War for the Planet of the Apes".

\section{METHODS}

The data source that used in this study is a movie entitled 'War for the Planet of the Apes'. This movie was premiered in New York City on July 10, 2017 and was theatrically released in the United States on July 14, 2017, by Fox. This movie was a commercial success having grossed over $\$ 490$ 
million and with durations 140 minutes. The researcher will use War for the planet of the Apes movie as the data study to find the moral judgment on it. The reason of choosing movie War for the planet of the Apes as the data source because this movie received a nomination for Best Special Visual Effects at the 71st British Academy Film Awards and was nominated for Best Visual Effects at the 90th Academy Awards. It was also nominated for four Saturn Awards, including Best Director for Reeves and Best Actor for Serkis. The data were collected by observation and note taking method. This study applied a descriptive qualitative method which is used to describe the types of moral judgment found in War for the Planet of the Apes and also the context of situation on the occurrence of moral judgment found in War for the planet of the Apes. The data analyzed by using the main theory by Trusted (1987) and supported by the theory of context of situation by Halliday (1985).

\section{RESULTS}

\section{RESULT AND DISCUSSION}

According to Trusted (1987), Moral judgment is verbally embodied in statement, sentences that assert that something or is not the case that can therefore be true or false. There are four types of the judgment; there are Logical/Mathematical, empirical, metaphysical, and value judgment. As mentioned previously this study focused on value judgment. Value judgment according to Trusted 1987: 30 is the distinctive of these judgments is that they are evaluations a standard that is knowledge by the person making the judgment. That means any judgment that a person make is based on his knowledge.

Table 1. Number of Moral Judgement

\begin{tabular}{c|cc} 
No & Types of Moral Judgement & Occurrences \\
\hline 1 & Value Judgment & 8
\end{tabular}

Based on the finding above, it showed the table of the categorization and occurrences of type of moral judgment and context of situation. As a result, there were found 20 type of moral judgment which consist of 8 value judgments, 4 logical judgments, and 2 empirical judgments. The analysis of these types of moral judgment is supported by the context of situation which influence the emergence these types. In this study, it is shown the difference amount of the data. The number of value judgment is more dominant than the other judgment it means in this movie the cast like to judge people by his opinion and knowledge because the script writer and the director of the movie wants to show how people can create a judgment directly no need to find the right reason to judge someone but its more about to show that we can do a judgment based on 
our experiences, opinion, and knowledge and that's also related to the meaning of value judgment.

\section{DISCUSSION \\ Data 1}

PREACHER : (nervous, quiet) ...it's... Alpha Omega. (Caesar just stares; then LANG, a lean female soldier, tattooed on her neck, speaks, quiet defiance under her fear)

LANG : Means we're the beginning and end. Humanity's survival depends on us. (Just then, the apes around Caesar turn, reacting to the arrival of - Maurice the orangutan. Like Caesar, he's older; there's a weariness in his eyes that suggests the war has taken a toll on his gentle spirit. Caesar turns to his old friend.)

MAURICE : (signs gravely) [Twenty-two dead. Many more injured.] Caesar glowers at the soldiers. We see Preacher still staring up at him... finally getting up the courage to utter:

PREACHER : You're him... You're Caesar. Caesar's eyes go to Preacher, caught off guard.

PREACHER : We've been looking for you for so long. We heard you had a hidden command base, but we could never find it. Some of us were starting to think you might be dead. But Colonel McCullough said no, you were out here somewhere...

From the utterance above, based on the context of situation of the scene, it tells about Preachers goes to forest accompanied by a group of apes as his army looking for Caesar and the other apes Preacher is following Colonel belief that Caesar and the other Apes are still alive (Field). Then finally they find who they are looking for. From the utterance above, it tells about when Preacher (tenor) who go to the forest with the other army to find the Apes because their leader named Colonel belief that Apes are still alive and live around there (mode). Fortunately, Preacher and the other army found the Apes in that forest.

From the data above, the utterance 'We heard you had a hidden command base, but we could never find it. Some of us were starting to think you might be dead. But Colonel McCullough said no, you were out here somewhere' can be considered as a moral judgment. The type of this judgment is value judgment. Trusted (1987) said that value judgment is about making judgment based on someone's knowledge. opinion. experiences. It can be seen from the utterance that Colonel believes that Caesar and another apes still alive and live somewhere out here. When Preacher found Caesar and his base it means what Colonel said before is 
the truth. Therefore, this utterance is concluded into value judgment. The value meant here is that even though some apes start to distrust the Colonel's belief, it still can be a glimmer of hope that guide them to keep on continuing the seek for Caesar, because Caesar is important for this colony because Caesar is the leader of the whole apes so if Colonel can control Caesar it will be easier to control the other apes to serve and work with human. Because to finish the wall need a nice teamwork so it can be finished as soon as possible.

\section{Data 2}

LANG : Shut up, man -

TRAVIS : What? They're animals, he's gonna slaughter us - (Caesar slowly steps toward him... Travis falls silent). (And at last CAESAR SPEAKS, a dark edge in his voice)

CAESAR : I... did not start this war. The humans all hold their breath, gaping up at him.

CAESAR : (CONT'D) The ape who did... is dead. His name was Koba. I killed him. (then, harder) I only fight now... to protect apes.

TRAVIS : (steeling himself) Yeah? What about him? (glances at Red) And we got ten more just like him.

CAESAR : I know these apes. They followed Koba... (looks Red dead in the eye) They tried to kill me. They fear what I will do to them. They believe I cannot forgive. So now they serve you... just to survive.

From the utterance above it tells about when Human come to forest to look for Apes especially Caesar (field). Caesar meet the other apes who stand with human named Travis (tenor). Caesar who is the leader of the apes tells the human that they were used to follow Koba which is get killed by Caesar so they are afraid of them that's why they decided to follow human to stay safe from them (mode).

From the data above, the utterance 'I know these apes. They followed Koba... (looks Red dead in the eye) They tried to kill me. They fear what I will do to them. They believe I cannot forgive. So now they serve you... just to survive' can be considered as a value judgment. It is because the judgment is based on Caesar experience. Caesar believes that Red and the other apes are not sincere in serving Travis because they are only trying to make them stay save from Caesar. They think that Caesar will kill them just like when he kill Koba, their leader.. It can be seen from the utterance that Caesar judged that Red and the other apes that follow koba just want to stay away from Caesar because Caesar had killed Koba. Red and the other apes think they will be safe with human. They also think that Caesar can do anything to them because now Caesar is the leader so the other apes who follow him will do anything as Caesar 
told. That is also the reason why the other apes who follow Koba before decided to serve human not Caesar anymore. Hence, Caesar tries to warn Travis about them, so that he don't trust those kind of apes completely. They can go away anytime they want they just looking for safety that's all if one day human can't give them safety they will leave human and go looking for another place to protect themselves. By knowing about the reason why the other apes follow human Travis can be more easier to handle that apes.

\section{Data 3}

RED : I no fear you! You must fear! How long you think woods can protect you? Humans destroy you. Their Kerna has all power. Humans follow all he says. To them, he is more than just human. He is everything. He looks over the apes, who seem chilled... his eyes boring into Winter's; the young gorilla is unnerved -

RED : He say: first Caesar die... then you all die. (He looks over the apes, who seem chilled... his eyes boring into Winter's; the young gorilla is unnerved)

This conversation is in Human Base Camp (Field) when two Apes that hate each other, Red and Caesar (tenor), talk each other. Red believes if he follows Colonel, he and his army will be safe. It is because Colonel leads the human that's why he will be easier to destroy the forest which is Apes's home with all of the stuffs that they have (mode). From the data above, the utterance 'Humans destroy you and Their Kerna has all power. Humans follow all he says. To them, he more than just human. He is everything.' can be considered as a moral judgment. The type of this judgment is value judgment because it is spoken based on Red experiences in dealing with Colonel. He tries to convince other apes who follow Caesar seeing Colonel that they will be safe with Colonel. Colonel has the power to destroy Apes base in the jungle since he is a human which has many war equipment. If they want to be alive, Red thinks that the Apes should obey the Colonel. Therefore, this utterance is concluded into value judgment.

\section{Data 4}

RED : You know Kerna shoot apes tomorrow... when wall is done. (Caesar's eyes shift briefly to Preacher's, who looks away). (Then he turns back to Red).

CAESAR : His wall is madness. It won't save him... any more than it will save you.

RED : I save myself.

CAESAR : Is there anything left... of you to save? (A brief flash of uncertainty passes over Red as he meets Caesar's piercing 
eyes... then he musters a final hard stare at Caesar, and turns to go).

From the utterance above it tells that when Red meet Caesar who want to meet Colonel. Red said that all the Apes who work to build the wall. From the data above, the utterance 'His wall is madness. It won't save him... any more than it will save you.' can be considered as a moral judgment. The type of this judgment is Value judgment. Trusted (1987) said that Value judgment is about making judgment based on knowledge, opinion, or even experiences of who make the judgment itself. It can be seen from the utterance that Caesar thought if the wall is finish it means it won't save anyone that live behind the wall if the wall is attacked by another army or anyone who hate human there. The wall will broke all the thing behind the wall. Caesar also can say like that because the Colonel who lead the army has many enemies from another country so it will be more easier for anyone to find Colonel's basecamp because of the wall is madness. So the enemy who find this base camp will try to broke the wall down for the first because they know the wall is their main shield of the base camp. Caesar knows it will happened one day this base camp will not safe if they have the madness wall like that it is really dangerous although it can protect the human but is not forever. They must be ready for any other attack by someone. Even Colonel has power and many army there will be more army that stronger than Colonel because there is no the strongest army in this world. The army is led by human and all humans have their own strength and weakness so there will be much way to defeat or win when having a war.

\section{Data 5}

(He looks to Rocket as well -- but Rocket's gaze is now fixed elsewhere). (Maurice and the others all turn to see - CAESAR has been following their conversation). (Finally, Luca signs, wracked with guilt)

LUCA : [Caesar... I think Winter betrayed us. I'm sorry. He was in my command.] (Caesar remains silent; then).

CAESAR : My youngest son... Have you found him yet?

LUCA : [We're still looking.] (Maurice turns to the others)

MAURICE : [Let's help them search.]

The dialogue is when Human suddenly attack Apes's home and kill some of the Apes (field). In this situation Luca said to Caesar (tenor) that Winter betrayed them (mode). By telling all about the Apes to human. Luca was confused how could human come to their base because no human knows about this place before but now they are there and destroy the apes' home. 
From the data above, the utterance '[Caesar... I think Winter betrayed us. I'm sorry. He was in my command.l' can be considered as a moral judgment. The type of this judgment is value judgment. This is due to the opinion of Luca. It can be seen from the utterance that Luca judged about one of them is betrayed them, his named is Winter. Luca judged this because he believes that Winter is the one who tells human about where the apes live so they can get inside and kill some of apes. Therefore, this utterance is concluded into value judgment.

\section{CONCLUSION}

Based on the discussion above, the movie is composed by types of moral judgment. There are 8 value judgment that can be found in War for the Planet of the Movie. The value judgment itself mostly come out from the main character in this movie the main character is Caesar but some of them also come from the support character. The characteristic of value judgment is that it should be based on the perspective, opinion, knowledge, and experiences of who make the moral judgment itself. The actions of the character who does the value judgment are determined by the judgment he makes. Moreover, from the movie can be seen that the judgments made are also give effects to the actions of the other characters. This value judgment will be easier to be analysed by using the theory of Halliday (1985) it is about context of situation. The contexts of situation are important to be noticed in order to get the proper value judgment from the movie.

\section{REFERENCES}

Amin, A. H. 2013. The Analysis of Moral Value Seen on: The War Horse Movie.Dissertation. Jawa Tengah Sidorejo: IAIN Salatiga University.

Bretz, S. 2017. Two models of moral judgment: Referencing, not plagiarism. Retrieved April 23, 2017, from

https://onlinelibrary.wiley.com/doi/pdf/10.1111/cogs.12517

Front, P. 2017. Frontier in psychology article: Referencing, not plagiarism. Retrieved June 22, 2017, from https://www.frontiersin.org/articles/10.3389/fpsyg.2017.01042/f ull

Halliday, M. A. K and Ruqaiya Hasan. 1985. Language Context and Text: Aspect of Language in a Social Semiotic Perspective, London: Deakin University

Production limit

Kenney, W. 1966. How to Analyze the Fiction. New York: Monarch Press.

Saputro, B. F. 2015. Analysis of Individual and Social Morality in the Movie: Down of the Plane of the Apes.Dissertation. Denpasar:UdayanaUniversity. 
Trusted, J. 1987. Moral Principles and Social Value, Taylor and Francis Elibrary: RoutledgeandKegan Paul Ltd.

Wellek, R., and Warren, A. 1956. Theory Literature, London: ThirtyBerdfortSquer.

Wonderly, M. 2009. Children's Film as: An Instrument Moral Education, Roudledge: Taylor and Francis Group. 